\title{
EVALUATION OF EFFICIENCY IN THE BANKING SYSTEM IN REPUBLIC OF MOLDOVA
}

\author{
PhD in Economics, Assistant Professor Lopotenco Viorica \\ Republic of Moldova, Chișinău, Academy of Economic Studies of Moldova
}

DOI: https://doi.org/10.31435/rsglobal_ijite/30042019/6452

\section{ARTICLE INFO \\ Received 19 February 2019 \\ Accepted 14 April 2019 \\ Published 30 April 2019}

\section{KEYWORDS}

banking system; banking efficiency; data envelopment analysis; intermediation approach

\begin{abstract}
The main objective of this study is to evaluate and analyze the efficiency of the banking system of the Republic of Moldova. To this end, efficiency is determined by the econometric approach, which is calculated by the ratio between outputs and inputs and can be described as the distance between inputs and outputs. For this purpose, the input-oriented CRS efficiency analysis was chosen, as well as the slack analysis of performance in DEAFrontier Software. The intermediation approach has been used in the banks' efficiency assessment. This approach regards the bank as an intermediary of financial services and assumes that banks collect funds for deposits with labor and capital and convert them into loans and other assets.

The conclusions of this study consist in the fact that through realized analysis the evolution of the efficiency of the Moldovan banking system over the last years, as well as the banks with problems in this chapter, has been highlighted.
\end{abstract}

Citation: Lopotenco Viorica. (2019) Evaluation of Efficiency in the Banking System in Republic of Moldova. International Journal of Innovative Technologies in Economy. 3(23). doi: 10.31435/rsglobal_ijite/30042019/6452

Copyright: (C) 2019 Lopotenco Viorica. This is an open-access article distributed under the terms of the Creative Commons Attribution License (CC BY). The use, distribution or reproduction in other forums is permitted, provided the original author(s) or licensor are credited and that the original publication in this journal is cited, in accordance with accepted academic practice. No use, distribution or reproduction is permitted which does not comply with these terms.

Introduction. The efficiency of the financial system can have an essential influence on the economic performance of a country. Thus, Amable and Chatelain [1] believe that the efficiency of the financial system can influence the growth of the population's economies, which can contribute to investment development. In general, the financial sector offers a better allocation of resources. However, the efficiency of the financial system is a complex economic concept, and its assessment can be extremely challenging - both quantitatively and qualitatively.

Under current conditions, the Moldovan banking sector, which accounts for $88 \%$ of the total financial system, can considerably increase gross domestic product volume, capitalize on new levels and reveal its potential for innovation. This requires qualitative mechanisms to assess the efficiency of the banking system, which in turn contributes to adapting participants to current risks and dynamic changes in the macroeconomic environment. The evaluation of the efficiency, as well as the possibilities for its growth through the analysis of the determinants, will determine the competitiveness of the Moldovan banking sector in the future.

The article is structured as follows. In the second section, there is a review of the literature on methods for assessing the efficiency of the banking system. The third section of the document is devoted to describing the empirical methodology of the research. The data and the results of the application of the methodology and their implications are analyzed in the fourth section. Finally, the conclusions are presented in Section Five.

Purpose of the study: The primary purpose of this study is empirical research on the efficiency of the banking sector in the Republic of Moldova. In the evaluation, is determined the efficiency of all banks in the Republic of Moldova and the efficiency of the banking system as a whole.

Literature review. In 1957, British economist M. Farrell published the article "Measurement of Production Efficiency," where he introduced the concept of "operational efficiency." Farrell has 
divided operational efficiency into two components: (1) technical or production efficiency; (2) allocation efficiency (distribution efficiency). [2] The first component describes how to maximize production with given resources. The second reduced to the minimal use of a combination of resources at a certain level of production.

According to this concept, the "efficiency index" of the banking system can be determined by measuring the point distance, describing the bank's operational process, from a specific efficiency boundary. Commercial banks, which correspond to this border, are fully capable, and as the distance from an inevitable efficiency border increases, the bank's inefficiency also increases. At the same time, the specified index may have values ranging from 0 to 1 (for example, a commercial bank with an index of 0.88 will be more effective than one with an index of 0.78 ). The inefficiency index is the difference between $100 \%$ and the actual efficiency index, expressed as a percentage.

The econometric approach is based on the notion of efficiency border. The efficiency of a bank or the banking sector is calculated based on the proximity of the values of the indicators of a particular bank or the entire sector (e.g., costs, the volume of services provided, etc.) at the potential or actual efficiency boundary. The efficiency boundary, in turn, is calculated based on the production function. Within the econometric approach, parametric and non-parametric methods develop in parallel, each with both advantages and disadvantages. Researchers do not give a definitive preference for any of them, because both techniques have advantages and disadvantages, and the choice of a method of assessing the appropriate bank efficiency is quite controversial. Besides, some researchers, for example, Huang and Wang, consider that choosing one of the methods may influence the conclusion on the efficiency and the implications of the policies derived from the analysis. [3] Contrary to this view, Toma et al. [4] believe that the two efficiency evaluation approaches (parametric and non-parametric methods) yield very correlated results in most cases.

Methodology and data. Assessing the efficiency of the banking system is a rather complicated analytical problem which requires solving some fundamental methodological tasks, in particular, because there are no generally accepted concepts on such notions as efficiency, the economic effect of the banking system or unified methodologies regards the indicators of the effectiveness assessment.

Our research is based on Farrell's (1957) study, which suggested that a company's efficiency consists of two components: technical efficiency and allocation efficiency. Technical efficiency reflects a company's ability to achieve maximum output from a set of inputs. On the other hand, allocation efficiency reflects the ability of a firm to use inputs in optimal proportions, given the prices and production technology. These two types of efficiency are then combined into a global economic efficiency that can be viewed from the perspective of input or output models. Then we can talk about overall cost efficiency (input perspective) or overall revenue efficiency (outlook perspective).

For the study was used data on the Moldovan banking sector, sources from the official website of the NBM, namely: Information on financial and economic activities of banks; Balance sheet of licensed banks; Profit or loss account.

The methodological procedure is based on several specific points or hypotheses underpinning and forms the research lines of the non-parametric DEA method. DEA is based on the explicit assumption of a production boundary that delimits the set of disposable inputs and results that can be obtained. The task of optimizing a selected DEA model is to construct a production frontier in a nonparametric manner and appropriately measure the distance between individual production units at the production frontier and capture it in the form of a score (used in assess the relative efficiency of a given production unit and compare it). However, it often happens that the production frontier will change over time (even this change is necessary for the theory of economic growth to be valid and owned). Although this is true, in specific consecutive periods, the production frontier due to the inertia of the economic environment can remain invariant in terms of a change in time.

If we rely on microeconomic theory, banks can be considered as firms with multiple inputs and outputs variables (fig.1).

In the analysis of banking efficiency, several approaches have been developed and used intensively: the production approach, the intermediation approach, the so-called modern approach [5]. Some sources also show the operating approach. 


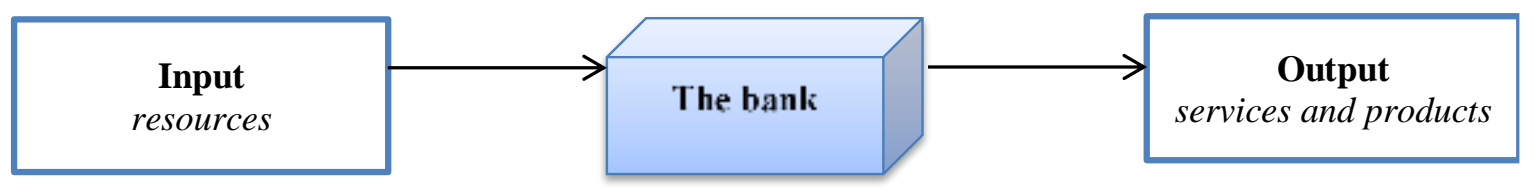

Fig. 1. „Input” and „Output” in banking

The distinctive features of these approaches are presented in the table below:

Table 1. The distinctive features of banking efficiency approaches

\begin{tabular}{|c|c|c|c|c|}
\hline & $\begin{array}{l}\text { Intermediation } \\
\text { approach }\end{array}$ & $\begin{array}{l}\text { Production } \\
\text { approach }\end{array}$ & $\begin{array}{l}\text { Operating } \\
\text { approach }\end{array}$ & $\begin{array}{l}\text { Modern } \\
\text { approach }\end{array}$ \\
\hline $\begin{array}{l}\text { Interpretation } \\
\text { for the bank }\end{array}$ & $\begin{array}{l}\text { a production unit } \\
\text { acting as a } \\
\text { financial } \\
\text { intermediary }\end{array}$ & $\begin{array}{l}\text { manufacturer of } \\
\text { deposits } \\
\text { (liabilities), loans } \\
\text { (assets) and other } \\
\text { services focused } \\
\text { on minimizing } \\
\text { cost of operations }\end{array}$ & $\begin{array}{l}\text { a production unit } \\
\text { that tends to } \\
\text { maximize profits }\end{array}$ & $\begin{array}{l}\text { a banking entity, } \\
\text { in which the } \\
\text { production model } \\
\text { endogenizes the } \\
\text { risk managers' } \\
\text { choice over } \\
\text { anticipated returns }\end{array}$ \\
\hline $\begin{array}{l}\text { Dominant } \\
\text { perspective }\end{array}$ & $\begin{array}{l}\text { macroeconomic } \\
\text { outlook }\end{array}$ & $\begin{array}{l}\text { microeconomic } \\
\text { outlook }\end{array}$ & $\begin{array}{l}\text { microeconomic } \\
\text { outlook }\end{array}$ & $\begin{array}{l}\text { microeconomic } \\
\text { outlook }\end{array}$ \\
\hline Main tasks & regulatory & customers & shareholders & managers \\
\hline
\end{tabular}

Each of these approaches can only be seen as a separate part of the entire banking activity. As far as the banking condition of the Republic of Moldova for macroeconomic stability promoted by the regulatory bodies, but also from the objectives proposed in the present study, it would be reasonable to apply the intermediation approach. The variables used in the model are described in the table below.

Table 2. Description the variables included in the model

\begin{tabular}{|l|c|}
\hline \multicolumn{1}{|c|}{ Variables } & Description \\
\hline$x_{1}:$ Total depozit & Total deposits attracted by the banking institution \\
\hline$x_{2}:$ Number of employees & Number of employees of the bank \\
\hline$x_{3}:$ Fixed assets & Total fixed Assets \\
\hline \multicolumn{2}{|c|}{ Outputs } \\
\hline$y_{1}:$ Total loans & Total loans granted \\
\hline$y_{2}:$ Other earning assets & Other earning assets that refer to non-loans \\
& activities \\
\hline
\end{tabular}

Next, we will try to evaluate the efficiency of the Moldovan banks for the period 2013-2018, based on the variables presented above, which were compiled from the database of the National Bank of Moldova. In order to assess the efficiency of banks has been used as mentioned above the intermediation approach proposed by Sealey and Lindley. [6] This approach regards the bank as an intermediary of financial services and assumes that banks are collecting deposit funds with the help of labor and capital and transforms them into loans and other assets. For each bank in the Moldovan banking system, it was necessary to select inputs, outputs, input prices, and production prices.

Empirical analysis and results. The primary purpose of this study is the empirical research on the efficiency of the banking sector in the Republic of Moldova. In the evaluation, the efficiency of all banks in the Republic of Moldova, as well as the efficiency of the banking system as a whole, was determined using the DEA assessment method - a non-parametric way of constructing the production frontier, which adequately measures the distance between individual units (DMU) at the production frontier and its reflection in the form of a score (used to assess the relative efficiency of a given production unit and benchmarking). DMUs on the frontier are described as having the best performances in the reference group, and the farthest ones are the least efficient. 


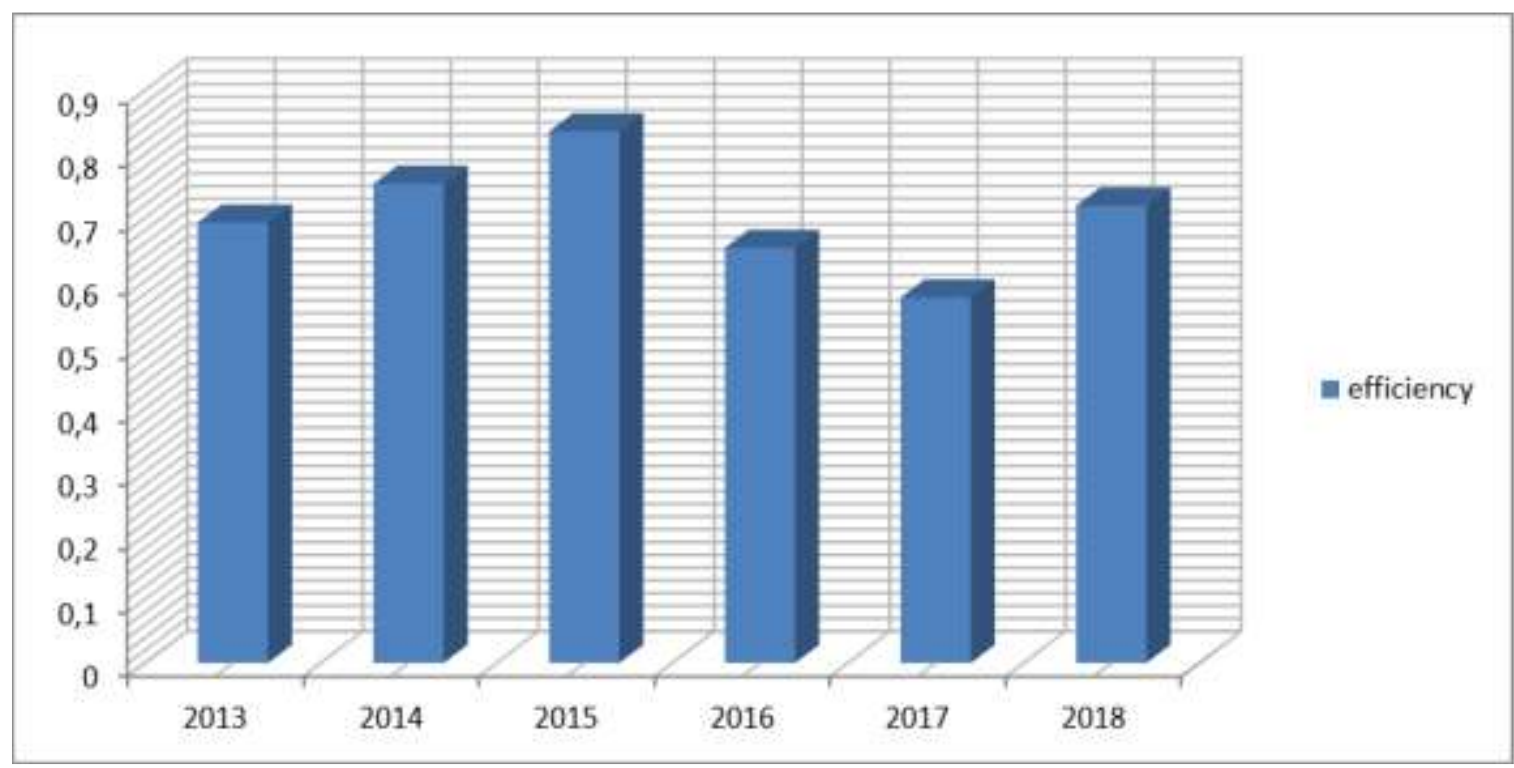

Fig. 2. Input-Oriented Banking Efficiency Evolution in the Republic of Moldova in 2013-2018

The analysis of the efficiency of the banking system in the Republic of Moldova through CRS, Input-Oriented (CRS Efficiency) shows a trend of a gradual increase in efficiency during the period 2013-2015 and a decrease in efficiency between 2015 and 2017. In 2018 there is an increase in the efficiency of the Moldovan banking system (fig.2). At the same time, it can be seen from the efficiency analysis that this is higher for small banks than for large banks (table 3).

Table 3. Input-Oriented Banking Efficiency in the Republic of Moldova, 2018

\begin{tabular}{|c|c|c|c|c|c|c|c|}
\hline & & $\begin{array}{c}\text { pput-Orien } \\
\text { CRS }\end{array}$ & Optimal Multipliers & & & & \\
\hline DMU No. & DMU Name & Efficiency & & & & & \\
\hline 1 & Total banking system & 0.71881 & 0.00001 & 0.00002 & 0.00012 & 0.00001 & 0.00000 \\
\hline 2 & BC "MOLDOVA - AGROINDBANK" S.A. & 0.94588 & 0.00005 & 0.00006 & 0.00041 & 0.00004 & 0.00000 \\
\hline 3 & B.C. "COMERTBANK” S.A. & 1.00000 & 0.00076 & 0.00167 & 0.00000 & 0.00000 & 0.00223 \\
\hline 4 & BC „EuroCreditBank” S.A. & 1.00000 & 0.00139 & 0.00000 & 0.00743 & 0.00106 & 0.00037 \\
\hline 5 & B.C. „ENERGBANK” S.A. & 0.86475 & 0.00051 & 0.00000 & 0.00298 & 0.00032 & 0.00034 \\
\hline 6 & B.C. „EXIMBANK” S.A. & 1.00000 & 0.00027 & 0.00074 & 0.00082 & 0.00000 & 0.00080 \\
\hline 7 & „FinComBank" S.A. & 1.00000 & 0.00043 & 0.00000 & 0.00252 & 0.00027 & 0.00029 \\
\hline 8 & BC "MOBIASBANCA - Groupe Societe Generale" S.A. & 0.68348 & 0.00011 & 0.00013 & 0.00092 & 0.00010 & 0.00000 \\
\hline 9 & BC „Moldindconbank” S.A. & 0.58784 & 0.00008 & 0.00000 & 0.00044 & 0.00005 & 0.00005 \\
\hline 10 & B.C. „ProCredit Bank” S.A. & 1.00000 & 0.00052 & 0.00000 & 0.00000 & 0.00011 & 0.00098 \\
\hline 11 & BCR Chisinau S.A. & 0.86456 & 0.00072 & 0.00195 & 0.00216 & 0.00000 & 0.00211 \\
\hline 12 & B.C. „VICTORIABANK” S.A. & 0.62283 & 0.00007 & 0.00018 & 0.00020 & 0.00000 & 0.00020 \\
\hline
\end{tabular}

Also important information can be obtained by applying DEA Frontier Software and namely is the possibility to build the reference set for each inefficient unit.

In our case, the reference set is wholly composed of DMUs operating near the inefficient unit. An interpretation of the benchmark set is that, if efficiency is to be improved, opportunities for improvement should be sought for the relevant banking institutions in the benchmark system. Lambda values are a measure of the relative importance of the other DMUs, which includes the reference set of a particular DMU. More specifically, lambda is a vector that describes the effective DMU percentages used for DMU to achieve a maximum efficiency score. Each inefficient unit could theoretically be moved to the efficient frontier and thus obtain an efficiency score equal to one, assuming that the underlying system can be restructured to improve the results. For each inefficient unit, a projection of the difference for each output can be obtained.

The input-oriented CRS efficiency analysis was performed, as well as the slack analysis of performance in DEAFrontier Software. The so-called slacks do not appear for efficient banks. They can only be seen at inefficient DMUs. However, slacks are only remaining portions of inefficiency; after the proportional input reduction or output increase, if the DMU cannot reach the efficiency limit (the target is efficiency), slacks are required to push the DMU to the limit (target). 
Table 4. Slacks report in the Moldovan Banking System 2018

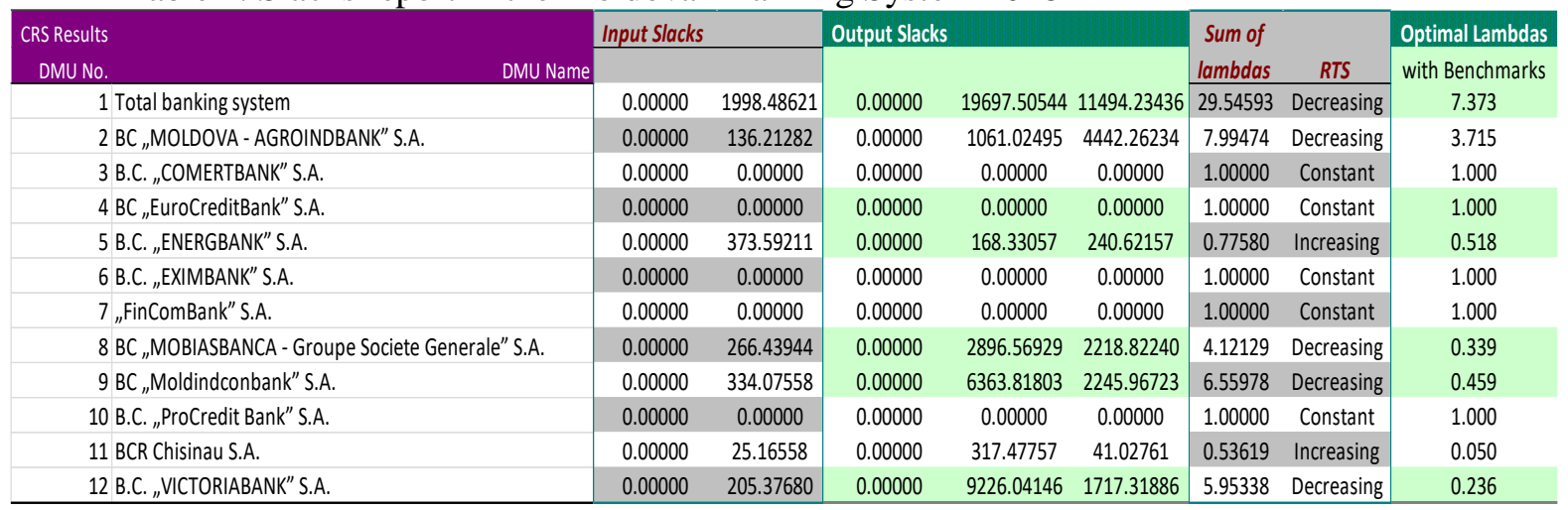

The slack analysis is quite useful for analyzing efficiency, especially when the benchmark set for each inefficient bank is built. This set can be seen on the right side of the tables, where the slack analysis is performed.

As a conclusion we can see that using a non-parametric DEA approach in assessing the efficiency of the banking system in the Republic of Moldova, the results show relatively low levels of efficiency, with averages between $65-85 \%$ recorded in different years of the analyzed period. Overall, the tests performed to demonstrate the existence of inefficient banks' techniques in the Republic of Moldova, which implies an average loss of resources (inputs) from the current level, generating the same level of outputs. It has also been demonstrated that the primary source of slacks in most Moldovan banks is technical and operational inefficiency and less than allocation.

From the above, we can see that the banking system can perform different financial intermediation, banking services provision and profit making. In recognition of this diversity, the application of non-parametric methods to the assessment of bank efficiency can clarify this issue and provide methodological notes to financial market regulators, commercial banks and shareholders, who are useful in measuring the technical efficiency of banking companies.

Conclusions. The banking system is an open system, and it is inextricably interconnected in the general economic system of the Republic of Moldova. In this respect, the most important problem to improve the institutional structure of the Moldovan banking system is that any of the best measures taken to improve it may be ineffective if they are not accompanied by the appropriate continuous improvement of the external environment Under the current conditions, the banking sector is able to considerably increase the volume of gross domestic product, capitalize on new levels and disclose its potential for innovation. This requires qualitative mechanisms to assess the efficiency of the banking system, which in turn contributes to adapting participants to current risks and dynamic changes in the macroeconomic environment. The evaluation of the efficiency, as well as the possibilities for its growth, will determine the competitiveness of the Moldovan banking sector in the future.

\section{REFERENCES}

1. Amable, B., Chatelain, J.B. Efficacité des systèmes financiers et développement économique. In:Revue Economie internationale. nr. 61 / 1995, p.99-130. ISSN: 1240-8093

2. Farrell, M. The Measurement of Productive Efficiency. In: Journal of the Royal Statistical Society. Series A. Vol. 120, No. 3 (1957), pp. 253-290 [online]. Disponibil: < https://www.jstor.org/stable/2343100>

3. Huang, M., Wang, MH. Comparison of economic efficiency estimation methods: Parametric and nonparametric techniques. In: The Manchester School, 70(5), 2002. pp. 682-709. ISSN: 1467-9957

4. Toma, P., Paolo, P., Zurlini, G., Valente, D., Petrosillo, I. A non-parametric bootstrap-data envelopment analysis approach for environmental policy planning and management of agricultural efficiency in EU countries. In: Ecological Indicators, 83, 2017. pp. 132-143. [online]. Disponibil: < https://www.sciencedirect.com/science/article/pii/S1470160X17304624?via\%3Dihub>

5. Hughes, J., Mester, L. Who said large banks don't experience scale economies? Evidence from a riskreturn-driven cost function. In: Working Paper Research Department, Federal Reserve Bank of Philadelphia, N. 13-13R, 2013

6. Sealey, C. W., Lindley, J. T. Inputs, Outputs and a Theory of Production and Cost at Depository Financial Institutions. In: Journal of Finance. Vol. 32, No. 8, 1977. pp. 1251-1266. [online]. Disponibil: < http://dx.doi. org/10.1111/j.1540-6261.1977.tb03324.x > 